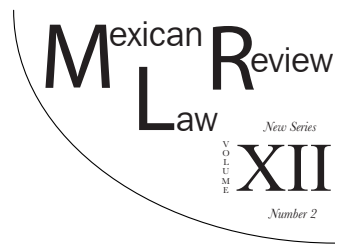

\title{
PROFESSIONAL MIDWIVES AND THEIR REGULATORY FRAMEWORK IN MEXICO
}

\author{
Liliana López AreLLANO* \\ Georgina SÁnchez RamíRez** \\ Héctor Augusto Mendoza Cárdenas****
}

\begin{abstract}
The objective of this article is to show the legal situation of professional midwives in Mexico with respect to their work. The implications of the human rights framework as established in Article 1 of the Mexican Constitution are explored as a basis to regulate professional midwifery. Using comparative analysis methodology, the contents of different regulatory frameworks for sexual and reproductive health in Mexico are studied, including those backed by international treaties and agreements. The results show that Mexican legislation includes midwifery to a certain extent, but fails to define concepts like the professionalization of midwifery, when midwives can work other than in hospitals, and they can be officially trained. Additionally, there is no legal recognition of this profession in educational and work standards. In conclusion, this research showes that there are enough international documents (agreements, conferences and recommendations) to serve as a frame of reference for redrafting Mexican standards, regulations and public policies on birth care provided by professional midwives. This would guarantee the safety of mothers who use midwifery services and give suitable professional training (with the respective creation of schools for this purpose) to the midwives who provide these services. Midwives would then be able to practice legally and help to improve maternal and reproductive health outcomes in the country.
\end{abstract}

* A doctoral student in ecology and sustainable development sciences at El Colegio de la Frontera Sur (ECOSUR) with a Degree in Surgery from the Universidad La Salle, a master's degree in Natural Resources and Rural Development from ECOSUR. Contact: llopeza@ecosur. edu.mx.

** Master's degree in Population from FLACSO, Mexico and a Ph.D. in Sexuality from the University of Salamanca, Spain. Contact: gsanchez@ecosurmx.

*** Master's degree in International Private Law from the Laval University of Quebec, Canada, and a Ph.D. in Legal Sciences from the School of Law and Criminology of the Universidad Autonóma de Nuevo León. Contact: hectormendoza@yahoo.com.mx.

Special thanks to Viridiana Sánchez Gruz for reviewing this document. 
Esta revista forma parte del acervo de la Biblioteca Jurídica Virtual del Instituto de Investigaciones Jurídicas de la UNAM

Keywords: Midwife, Professional Midwives, Birth Care, Regulation, Certification.

RESUMEN: La presente investigación tiene como objetivo mostrar la situación legal de las parteras profesionalizadas de México, en relación al ejercicio de su trabajo, se exploran las implicaciones de considerar el marco de los Derechos Humanos, como se establece en el Art. $1^{\circ}$ de la Constitución, como base para la regulación de la partería profesionalizada, utilizando como metodología el análisis comparativo de contenidos de diversos marcos regulatorios en materia de salud sexual y reproductiva en nuestro país, pero amparados en tratados y convenios internacionales. Los resultados muestran que la legislación mexicana contempla la partería hasta cierto punto, pues faltan definir conceptos como lo que se entiende por partería profesionalizada, en dónde pueden laborar - más allá de los espacios hospitalarios -, los sitios donde se puedan formar con validez oficial, asi como dar sustento jurídico al reconocimiento de su profesión, mediante estándares educativos y laborales. A manera de conclusión, se muestra en este trabajo que existen suficientes documentos internacionales (convenciones, conferencias y recomendaciones) que pueden ser un marco de referencia para la reelaboración de normas, reglamentos, así como de políticas públicas, sobre la atención al nacimiento por parteras profesionalizadas en nuestro país de manera regulada, que garanticen la seguridad tanto a madres usuarias de sus servicios como a las parteras que los proporcionan, con una formación profesional adecuada (con la correspondiente creación de escuelas) para hacer frente a los retos de la salud en el país, ejerciendo su trabajo sin el riesgo de que esto suceda en medio de un vacio legal.

Palabras Clave: Partera, parteras profesionalizadas, atención al parto, regulación, certificación.

\section{TABle OF Contents}

I. INTRODUCTION

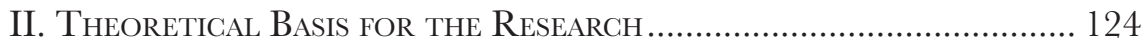

III. The Gurrent Situation of Professional Midwives in Mexico..... 130

IV. Main Difficulties in Practicing Midwifery in Mexico ................... 132

V. Discussion: Criticism and Proposals for National Legal

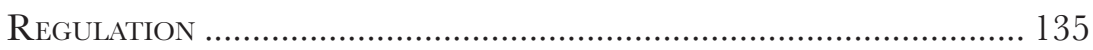

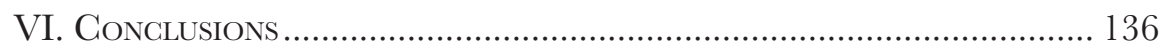




\section{INTRODUCTION}

It is important to begin this article with the definition of professional midwife. The International Confederation of Midwives $(\mathrm{ICM})^{1}$ defines it as follows:

A midwife is a person who has successfully completed a midwifery education programme that is based on the ICM Essential Competencies for Basic Midwifery Practice and the framework of the ICM Global Standards for Midwifery Education and is recognized in the country where it is located; who has acquired the requisite qualifications to be registered and/or legally licensed to practice midwifery and has the title 'midwife'; and who demonstrates competency in the practice of midwifery.

Mexico has only two officially recognized midwifery schools in the country: the Centro para los Adolescentes de San Miguel de Allende, a nonprofit organization (CASA) ${ }^{2}$ in Guanajuato and the Escuela de Parteras Profesionales del Estado de Guerrero, a state school. ${ }^{3}$ Another way to study birth care is by obtaining a nursing and obstetrics degree, ${ }^{4}$ which gives the person the status of a nurse rather than a professional midwife.

Official Mexican Standard 007 (NOM007-SSA2-2016) ${ }^{5}$ on the care of women during pregnancy, childbirth and postpartum, and of newborns recognizes two types of midwives: 1) the Technical Midwife, defined as a person who has graduated from a midwifery training school, whose degree is recognized by the relevant authorities and corresponds to a technical level; and 2) the Traditional Midwife, understood as a person who belongs to indigenous and rural communities, has been trained in and practices the traditional model of care for pregnancy, childbirth, postpartum, and the newborn; and is considered a non-professional, but is authorized to provide this type of care. ${ }^{6}$

NOM007 does not explicitly define whether a technical midwife is synonymous with a professional midwife, or if a degree in nursing and obstetrics is

1 The ICM is an international organization. More information can be found at https:// werere.internationalmidwives.org/about-us/international-confederation-of-midwives/.

2 Centro para los Adolescentes de San Miguel de Allende Asociación Civil A.C (CASA) (Accessed on February 28, 2019 at 8:23PM) https://casa.org.mx/.

3 See http://guerrero.gob.mx/articulos/marco-juridico-de-la-escuela-de-parteras-profesionales-del-estado-de-guerrero-opd/Accessed on March 16, 2018, 11:23 a.m.

4 Graciela Freyermuth, Hilda Argüello, Viejos y nuevos rumbos de la partería profesional, in ImAGEN INSTANTÁNEA DE LA PARTERÍa 21-48 (Georgina Sánchez comp., 2015).

5 Mexican Official Standard 007 (NOM007-SSA2-2016) on the Care of Women during Pregnancy, Childbirth and Postpartum, and of Newborns (NOM007-SSA2-2016, Disposición General 5.5.11), Diario Oficial de la Federación [Federal Official Gazette - DOF 07/04/2016] (Mex.).

6 Mexican Official Standard 007 (NOM007-SSA2-2016) about women and newborn care during pregnancy, childbirth and post partum, Dario Oficial de la Federación [DOF 07/04/2016] (Mex.). 
equivalent to a degree in midwifery. This is important if one bears in mind that there are international proposals from the United Nations Population Fund (UNPF), the World Health Organization (WHO) and the $\mathrm{ICM}^{7}$ that encourage and promote professional midwives as a first line of care, especially in developing countries.

International organizations like the UNPF, WHO and Pan-American Health Organization (PHO) have done studies that prove the importance of midwifery services, the demand for which continues to increase because the care provided is different than that at a hospital in that it is less invasive, centered on the mother's needs and less expensive. Consequently, member countries have been asked to consider professional midwives as the first level of care. These international organizations propose establishing or bolstering midwifery schools, advancing and validating this field of work, as well as granting it official recognition in order to achieve these goals. ${ }^{7}$

The objective is to improve the quality of care in this area and to see midwives as an important asset to health care resources in places like Mexico. Most importantly, obstetric violence (understood as any lack of respect during labor, childbirth and postpartum, which can be serious and range from verbal and psychological abuse, ignoring women in labor, performing medical procedures without informed consent, the use of coercion, lack of confidentiality and lack of privacy to physical abuse or refusing to give medical care) should also be taken into account. ${ }^{8}$ Obstetric violence includes one particular phenomenon that can be observed worldwide: an increase in the number of C-sections. Between January 2009 and September 2014, for every 100 registered births in Mexico, 46 were $\mathrm{C}$-sections and 54 were natural births. ${ }^{9}$ The number of $\mathrm{C}$-sections has increased by $1 \%$ each year since $1999 .{ }^{10}$ Between 2000 and 2012, there was a 50.3\% increase in C-sections with the biggest increase occurring in the private sector, followed by social care, ${ }^{11}$ which is

7 UNPF, WHO, ICM. El estado de las parteras en el mundo 2014. HACIA EL ACCESO UNIVERSAL A la Salud, un derecho de La mujer. Fondo de Población de las Naciones Unidas (2014).

CPMSVCH, OMS, OPS, UNFPA, El ESTAdo DE LAS PARTERAS EN EL MUNDO: OportuniDADES Y RETOS PARA MÉXICO (2014).

8 Rosario Valdez et al., El abuso hacia las mujeres en salas de maternidad: nueva evidencia sobre un viejo problema. Resumen ejecutivo. 1-26 (Instituto Nacional de Salud Pública, 2013). See Joaquina Erviti et al., Sociología de la práctica médica autoritarIA. VIOLENCIA OBSTÉTRICA, ANTICONCEPCIÓN INDUCIDA Y DERECHOS REPRODUCTIVOS (UNAM, CRIM 2015).

9 inegi, Encuesta Nacional de la Dinámica Demográfica, Nota Técnica (2015). (OCT 21, 2016, 2:08PM) http://www.inegi.org.mx/saladeprensa/boletines/2015/especiales/especiales2015_07_1.pdf.

10 Esteban Puentes-Rosas et al., Las cesáreas en México: tendencias, niveles y factoRes Asociados 16-22:46. (Salud Pública de México) (2004).

11 Leticia SuÁrez-López et al., Características socio demográficas y reproductivas asociadas con el aumento de cesáreas en México. Salud Publica de México. Vol. 55 suplemento 2 (2013). 
particularly relevant here because of such high numbers. ${ }^{12}$ The care given by professional midwives could reduce the number of such events and decrease maternal mortality. ${ }^{13}$ Between 1990 and 2013, the number of maternal deaths in Mexico dropped by 53\%, ${ }^{14}$ going from 88.7 deaths per 100,000 live births to 38.2 per 100,000 in $2013 .{ }^{15}$ In 2015, Mexico registered 38 deaths per every 100,000 live births. ${ }^{16}$ This decrease is recorded in a document on the status of midwives in the world and universal access to health care, which according to the UN Population Fund is a basic right for women.

In Mexico, Leslie Cragin, et al., (2011) made a comparison of the academic training of general practitioners, obstetric nurses and professional midwives based on the essential competencies established by the ICM. Results showed that professional midwives received the best education, followed by nurses and finally, general practitioners. ${ }^{17}$

In another study by Walker, et al., the research team implemented a pilot care model in three rural medical units belonging to the health departments of the states of Guerrero and Oaxaca, and compared the quality of care among general practitioners, obstetric nurses, and professional midwives. The results mention that professional midwives were the best trained to attend to low risk births, ${ }^{18}$ followed by obstetric nurses and lastly general prac-

12 INEGI, Encuesta nacional de la dinÁmica demográfica, Nota técnica (2015). (Oct 21, 2016, 2:08PM) http://wrwre.inegi.org.mx/saladeprensa/boletines/2015/especiales/especiales 2015_07_1.pdf.

Esteban Puentes-Rosas et al., Las cesáreas en México: tendencias, niveles y factores asociados 16-22:46. (Salud Pública de México) (2004).

Leticia Suárez-López et aL., Garacterísticas socio demográficas y reproductivas asociadas con el aumento de cesáreas en México. Salud Publica de México. Vol. 55 suplemento 2 (2013).

13 Maternal mortality is defined as a mother's death during pregnancy, childbirth and up to 42 days after childbirth.

14 Graciela Freyermuth, Determinantes sociales en la Mortalidad Materna en México, REvista CONAMED, 21 (1), 25-32 (2016).

15 Un México. 2016. Objetivos de Desarrollo del Milenio (September 15, 2016, 2:44PM) http://wrwronu.org.mx/agenda-2030/objetivos-de-desarrollo-del-milenio/.

16 World Bank. 2015. Tasa de Mortalidad Materna. (OCt 21, 2016 2:48PM) http://datos. bancomundial.org/indicador/SH.STA.MMRT?name_desc =true.

17 Leslie Cragin, Lisa De Maria, Lourdes Campero, Dilys Walker. Educating Skilled Birth Attendants in Mexico: Do the Gurricula Meet International Confederation of Midwives Standards? Reproductive Health Matters. Vol 15:30, p. 50-60 (2007), (Oct, 19, 2016) http://ac.els-cdn.com/S0968808007303327/1-s2.0-S0968808007303327-main.pdf? tid $=d 687 b d 6 c-9626-11 e 6-a 23 a-$.

18 A low risk birth is one that is expected to take place without any complications. To reach this determination/conclusion, several factors are considered: the woman's monthly checkups; clinical tests like biometrics, urine samples and blood tests that detect sexually transmitted diseases; and ultrasounds. When these and physical examination results are within the normal range, these births are deemed low risk in view of the fact that the WHO estimates that of 100 births under these conditions, only 10 to $15 \%$ experience complications. 
Esta revista forma parte del acervo de la Biblioteca Jurídica Virtual del Instituto de Investigaciones Jurídicas de la UNAM

titioners. In addition, professional midwives provided better prenatal care, postnatal care and breastfeeding support to the mothers who went to health centers. Therefore, the authors support the benefits of birth care by professional midwives. ${ }^{19}$

The National Institute of Public Health has recently carried out studies on the "holistic model of midwifery care" (modelo integral de partería), ${ }^{20}$ the findings of which coincide with international approaches ${ }^{21}$ and that of Walker et al., indicating that midwife services are safe for healthy women with low risk births, and ideal for primary care. ${ }^{22}$

Nonetheless, the Official Mexican Standard 007 legalizes and encourages the transferal of a pregnant woman to the hospital by a midwife, effectively placing birth care under the responsibility and control of the hospital. Due to pressure from the passage of the standard 007, women who live in urban areas are stigmatized by medical personnel if they choose to use a midwife to attend their birth. The use of a midwife by women in rural indigenous communities is looked upon more leniently because they live further from the hospital. ${ }^{23}$

We believe it is important to explore the standards and regulations in Mexico pertaining to the training and practice of professional midwives and thereby demonstrate their legal situation in relation to their work. At the same time, we explore the implications of the human rights framework used as a basis for the regulation of professional midwives. To this end, various regulatory frameworks in the area of sexual and reproductive health were used to make a comparative analysis.

\section{TheORETICAL BASIS FOR THE Research}

The discussion about respecting sexual and reproductive rights as a part of human rights is nothing new. With the Declaration of Alma Ata in the 1970s,

19 Dilys Walker, Leticia Suárez, Dolores González, lisa DeMaria, Minerva RomeRo. PARTERAS PROFESIONALES tÉCNICAS Y ENFERMERAS OBSTETras: ¿UNA OPCiÓN PARA LA ATENCIÓN Obstétrica en México? 80 (Instituto Nacional de Salud Pública, Instituto Nacional de las Mujeres 2011).

20 Instituto Nacional de Salud Pública, Modelo Integral de Partería (Feb, 28, 2019, 10:54AM) http://www.modelointegraldeparteria.com/

21 Patricia Janssen et al., Outcomes of Planned Home Birth With Registered Midwife Versus Planned Hospital Birth With Midwifery or Physician, 181(6-7) Canadian Medical Association Fournal 377-383 (2014).

Elizabeth Schroeder et al., Cost Effectiveness of Alternative Planned Places of Birth in Woman At Low Risk of Complications: Evidence From the Birthplace In England National Prospective Cohort Study, 344 BRITISH MEDICAL JOURNAL E2292 (2012).

22 Dorothy Shaw et al., Drivers Of Maternity Care In High Income Countries: Can Health Systems Support Women-Centered Care Vol. 388 (10057) THE LANCET, 2282-2295 (2016).

23 Mexican Official, supra note 6. 
the WHO/International Conference on Primary Health Care clearly established access to health care is a human right. This declaration is important in view of the vast differences in the health disparities between developed and developing countries (see, for example, the work of Yamin Alicia). ${ }^{24}$ Despite clear evidence of this, there are still those who claim that socio-economic and structural inequalities are not a cause of the rampant mortality in the world's most vulnerable populations.

In regards to sexual and reproductive rights, declarations from the Cairo (1994) and Beijing (1995) world conferences on women clearly point at why these rights are inherent to humankind in general, but particularly important for women and children in view of the dominant patriarchal system that regulates the culture surrounding women's bodies, sexuality, reproduction, autonomy and health.

Since the Cairo and Beijing conferences, Mexico has established precedents on women's sexual and reproductive rights. Article 4 of the Constitution clearly establishes that men and women are equal before the law and that everyone has the right to make free, responsible and informed decisions regarding the number and frequency of their children, as well as a right to health. ${ }^{25}$

In the same way, Article 3, paragraph IV of the General Health Law defines maternal-child care as a matter of general health. Article 61 of the same law recognizes this type of care as a priority and includes caring for mothers during pregnancy, childbirth and postpartum, as well as caring for the newborn and monitoring their growth and development at later stages.

There are also very specific regulations published in the Official Federal Record (DOF in Spanish), such as the above-mentioned Official Mexican Standard 007-SSA2-2016 (published on February 17, 2017), which centers on the care of women during pregnancy, childbirth and postpartum, as well as care for the newborn; and recognizes the contributions of technical and traditional midwives. As stated above, these regulations must be followed by national health system institutions - whether public, private or social. Noncompliance will be punished or fined according to the jurisdiction. This standard also refers to other regulations, such as NOM-005-SSA2-1993 which pertains to family planning services.

In this article, NOM007 will be frequently mentioned because sexual and reproductive rights are an important part of human rights. Article 1 of the Constitution establishes that:

In the United Mexican States, all individuals are entitled to the human rights granted by this Constitution and the international treaties signed by the Mexican State, as well as to the guarantees for the protection of these rights. Such

24 See https://wrwr.linkedin.com/in/alicia-ely-yamin-32359114/es.

25 JUstia MÉxico (MAR 52019 10:44AM) https://mexico.justia.com/federales/constitucionpolitica-de-los-estados-unidos-mexicanos/titulo-primero/capitulo-i/\#articulo-4. 
human rights shall not be restricted or suspended, except for the cases and under the conditions established by this Constitution.

The provisions relating to human rights shall be interpreted according to this Constitution and the international treaties on the subject, working in favor of the broader protection of people at all times.

All authorities, in their areas of competence, are obliged to promote, respect, protect and guarantee Human Rights, in accordance with the principles of universality, interdependence, indivisibility and progressiveness. Asa consequence, the country must prevent, investigate, penalize and rectify violations of Human Rights, according to the law.

$[\ldots]$

Any form of discrimination, based on ethnic or national origin, gender, age, disabilities, social status, medical conditions, religion, opinions, sexual orientation, marital status, or any other form, which violates human dignity or seeks to annul or diminish the rights and freedoms of the people, is prohibited. ${ }^{26}$ (Constitutional reform of June 10, 2011).

It is therefore clear that in Mexico, issues regarding pregnancy, childbirth and postpartum are covered by the human rights stipulated in Article 1 of the Constitution and in the regulations and laws cited above.

However, in the case of professional midwives, how are they connected to guaranteeing the human rights of women of reproductive age in Mexico? According to our analysis, the link between professional midwives and human rights is that midwives are another option for women, not just for supervising pregnancy, but also for assisting in childbirth, postpartum and other areas related to women's sexual and reproductive health (such as pap smears and contraception, among others), which are a fundamental part of a women's human rights.

Articles 1 and 4 of the Constitution make room for different care alternatives, allowing women to exercise the right to information, which should be clear, opportune and based on scientific evidence in order to decide where, how, when and with whom to give birth.

In addition, these articles effectively establish a commitment that the services women receive must respect both physical and emotional needs, and not put either the mother or the newborn at risk. Professional midwives should perform their clinical practice evidence-based, and when necessary, the prompt and prudent use of appropriate medical technology -everything to safeguard the lives of the mother and the newborn. Through this interpretation of the constitution, a woman's right to comprehensive and safe sexual and reproductive care and her right to receive violence-free treatment is clearly protected, as stipulated by human rights.

The Universal Declaration of Human Rights establishes the free development of personality as a fundamental right, which is directly related to

26 Fustia MÉXICO (MAR 5 2019, 10:46) https://mexico.justia.com/federales/constitucion-politica-delos-estados-unidos-mexicanos/titulo-primero/capitulo-i/\#articulo-1. 
autonomous decision-making as in the case of mothers who decide to have a midwife to attend a birth. It is important to mention that autonomous decision-making implies that actions should not harm third parties, thus the midwife is obligated to act in the best interest of the mother and her newborn.

Related to this, the Mexican Supreme Court has clearly established that:

As a higher fundamental right recognized by the Mexican legal system, human dignity is the basis for, among other highly personal rights, the right of every individual to freely and independently choose his or her life project. Therefore, according to comparative jurisprudence and case law, such right is the State's recognition of every individual's inherent power to be the individual he or she wants to be, without coercion or unjustified controls, in order to achieve the goals or objectives he or she sets according to his or her values, ideas, expectations, tastes, etc. Thus, the free development of personality means, inter alia, the freedom to marry or not to marry; to have children and how many, or decide not to have any; to choose one's personal appearance; one's profession or work, as well as free choice of sexual preference, inasmuch as all these aspects are part of the way in which a person wishes to project him or herself and live his or her life and that, consequently, it falls to him or her alone to decide independently. ${ }^{27}$

The work of professional midwives is connected to human rights in two ways: the first concerns the people who use their services, and which, in our opinion, includes women's right to choose the place and type of care they want to receive at the moment of childbirth. The second concerns professional midwives as health care providers. There are a series of fundamental rights that should be taken into account, such as the right to education, labor rights, rights related to professional freedom and, of course, sexual and reproductive rights because this is the sphere in which midwives practice.

This is upheld by Article 5 of the Constitution, which supports the choice of profession, as long as it is lawful. Additionally, this article states that the law of each state shall determine which professions require a degree to be practiced, the requirements for such degree and the corresponding authorities to issue said degree. ${ }^{28}$

NOM007 defines pregnancy as a physiological event, and thus should be treated with dignity. It also mentions that "low-risk term deliveries can be attended by obstetric nurses, technical midwives and trained traditional midwives". ${ }^{29}$ At the same time, this regulation mentions the need to promote

27 See inter alia, Court Opinion number 165822 p. lxvi/2009 Pleno. Novena Época. Semanario Judicial de la Federación y su Gaceta. Volume XXX. December 2009.

See also the 22nd and 29th articles from the Universal Declaration of Human Rights. adopted and proclaimed by the General Assembly december 10, 1948.

28 Political Constitution of the United Mexican States, article 5 [const.], as amended Jan 29, 2016, Diario Oficial de la Federación [D.O.F.], February 5, 1917 (Mex.).

29 Mexican Official, supra note 6. 
vertical births, limit episiotomies, ${ }^{30}$ encourage immediate breastfeeding, late clamping of the umbilical cord, which, as will be seen below, are actions carried out by professional midwives.

In addition to the legislative documents mentioned above, there is also the 2009 General Agreement on Inter-Agency Collaboration for Obstetric Emergency Care. This convention establishes that a mother in an obstetric emergency can be attended at any national or state health institution (whether part of the Mexican Social Security Institute, the Institute for Security and Social Services for State Workers or the Ministry of Health) without necessarily being a member of that particular system. The criterion for the choice of hospital is distance, meaning that the patient experiencing an obstetric emergency can go to the nearest hospital for help, and thus prevent any possible complications or maternal mortality. ${ }^{31}$

Within the international framework, we can also find documents that support the regulation of professional midwives, like the 1979 and 1994 Conventions on the Elimination of all Forms of Discrimination against Women, which obligates signatory countries to enact laws and provisions that promote and protect gender equality. ${ }^{32}$ Even so, two common forms of discrimination against midwives can be observed. The first that affects midwives is that their fundamental right to exercise their chosen profession is not respected in places where midwifery is not recognized as a profession. The second type of discrimination happens when women go to midwives and later are denied of various fundamental rights by medical personnel, as mentioned above, including free development of their personality because these women are labelled as irresponsible or ignorant for using midwifery services.

Another important document is the WHO Recommendation for Childbirth: the 1985 Fortaleza Declaration. This text clearly establishes that women have the right to prenatal care and to play a central role in all its aspects. General and specific recommendations are also given for taking caring of women during childbirth. ${ }^{33}$

The 1994 International Conference on Population and Development in Cairo addressed the importance of satisfying men's and women's needs through access to education and health services, as well as increased employment opportunities. It also widely touched upon the topic of sexual and re-

30 This is the cut made to the perineum, between the anus and the vagina, in order to enlarge the birth canal at the moment of birth.

31 Ssa General Agreement on inter-agency collaboration for obstetric emergencies care (september 4, 2018, 10:02am) http://wwrw.ccinshae.salud.gob.mx/descargas/atencion_de_la_emergencia_obstetrica.pdf.

32 PAHO, Gender EQuality Policy 2009 (october, 10, 2017, 10:46AM) http://wrere.paho. $\mathrm{org} / \mathrm{hq} /$ index.php?'option $=$ com_docman E'task $=$ cat_view E'gid $=6813$ E'itemid $=270$ Elang $=e$.

33 Who, who Recommendations for Childbirth Fortaleza Declaration 1985 (october 10, 2017, 10:46) http://wrwreunizar.es/med_naturista/tratamientos/recomendaciones $\% 20$ de $\% 20$ la\%20 oms $\% 20$ sobre\%20el\%20nacimiento.pdf. 
productive rights, which broadened traditional ideas centered solely on family planning. ${ }^{34}$

Likewise, the 1995 Fourth World Conference on Women Beijing Declaration promotes women's rights and gender equality - including the right to enjoy a life free of violence, the right to education, equal pay for equal work and the explicit recognition of all women to control all aspects of their health, ${ }^{35}$ which in no way excludes pregnancy and birth.

Lastly, the 2000 World Millennium Development Goals includes ideas for promoting gender equality and women's autonomy, reducing infant mortality and improving women's health. ${ }^{36}$

It is important to mention that there are other documents that are not legally binding but establish precedents on how professional midwives operate, such as the discussions at the 2000 International Conference on the Humanization of Childbirth, in Ceara, Brazil, which established the principles of respectful attention centered on the mother and her family at the moment of birth, as well as holistic treatments which take into account the context of women's social, emotional and health. However, the conference did not culminate in any formal agreements. ${ }^{37}$

Another organization should be mentioned because of its importance in the region is the Regional Conference on Women in Latin America and the Caribbean ${ }^{38}$ which has had meetings in:

Argentina 1994: Urging signatory countries to establish actions to protect and promote women's reproductive rights.

Lima 2000: Emphasizing the protection of women's human rights, including sexual and reproductive rights.

Quito 2007: Recognizing that heath is a key issue for women's rights and discussing integrated health services.

Brasilia 2010: Recommending that countries reform their abortion legislation in order to provide safe treatments for women.

Santo Domingo 2013: Proposing safe abortion services for women who do not want to become mothers at the time and ensuring that health services are not violent against women.

34 UNPF. Programme of Action - Adopted at the International Conference on PopuLation and Development Cairo (2004) (Feb, 28, 2019, 8:05PM) https://wrere.unfpa.org/sites/ default/files/event-pdf/PoA_en.pdf.

35 Fourth World Conference on Women, Bejjing 1995 (october 11, 2017 9:50AM) http://www.unwomen.org/es/how-we-work/intergovernmental-support/world-conferences-on-women.

36 Un Millennium Development Goals, 2000 (october 11, 2017, 11:00Am) http://wrere. onu.org.mx/agenda-2030/objetivos-de-desarrollo-del-milenio/.

37 Declaration on Humanizing Childbirth (october 11, 2017 10:24am) http://wrere. tobinatal.com.ar/humanizacion/ceara.html.

38 Cepal, Regional Conference About Latin America and Carribean Women (OcTOBER 9, 2017, 10:58AM) https://oig.cepal.org/sites/default/files/folleto_conferencias_regionales_c1500 106.pdf. 
Esta revista forma parte del acervo de la Biblioteca Jurídica Virtual del Instituto de Investigaciones Jurídicas de la UNAM

In addition, international organizations like UNFPA, WHO, PAHO and the ICM have studied the situation of midwives around the world. Their findings were compiled in the 2014 report, which made projections about midwifery to 2030. Their proposals are focused on improving midwives' working, training and legal conditions through activities such as promoting, extending and regulating midwifery studies; normalizing, ordering and regulating childbirth care given by professional midwives; and promoting and strengthening contact between midwives. Mexico is considered a signatory country. ${ }^{39}$

To explore this in more in, the next section discusses professional midwives in Mexico - their current situation and the problems they face.

\section{The Gurrent Situation of Professional Midwives in Mexico}

As mentioned in the introduction, professional midwives study the subjects of pregnancy, childbirth and postpartum, breastfeeding and women's sexual health. In Mexico, the way to access such training with official recognition is through the non-profit Centro para los Adolescentes de San Miguel de Allende A.C (CASA) in Guanajuato or the Escuela de Parteras Profesionales in Tlapa de Comonfort in the state of Guerrero. However, there are people with degrees in nursing and obstetrics who work as midwives, medical doctors who take up midwife care, and women who have trained abroad and work as midwives in Mexico. In addition, there are midwifery schools although the training given is not officially recognized (see Table 1).

TABLE 1

\begin{tabular}{|l|l|c|l|l|}
\hline \multicolumn{1}{|c|}{ SCHOOL1 } & LOCATION & $\begin{array}{c}\text { FOUNDING } \\
\text { DATE }\end{array}$ & $\begin{array}{c}\text { LEGAL } \\
\text { STATUS }\end{array}$ & $\begin{array}{l}\text { OFFICIAL } \\
\text { RECOGNITION } \\
\text { STATUS }\end{array}$ \\
\hline $\begin{array}{l}\text { Centro para } \\
\text { los Adoles- } \\
\text { centes de } \\
\text { San Miguel } \\
\text { de Allende } \\
\text { Asociación } \\
\text { Civil (A.C.) } \\
\text { "CASA"2 }\end{array}$ & $\begin{array}{l}\text { San Miguel } \\
\text { de Allende, } \\
\text { Guanajuato }\end{array}$ & 1997 & $\begin{array}{l}\text { Non-profit } \\
\text { organization }\end{array}$ & $\begin{array}{l}\text { Officially rec- } \\
\text { ognized by the } \\
\text { Guanajuato State } \\
\text { Health Depart- } \\
\text { ment. Agreement } \\
\text { 176-97 of July } \\
\text { 4, 1997. C.C.T. } \\
\text { 11PETO143N }\end{array}$ \\
\hline $\begin{array}{l}\text { Luna Llena } \\
\text { A.C. } 3\end{array}$ & Oaxaca & 2009 & $\begin{array}{l}\text { Non-profit } \\
\text { organization }\end{array}$ & None \\
\hline $\begin{array}{l}\text { Mujeres } \\
\text { Aliadas A.C.4. }\end{array}$ & $\begin{array}{l}\text { Erongarícua- } \\
\text { ro, Michoa- } \\
\text { cán }\end{array}$ & 2010 & $\begin{array}{l}\text { Non-profit } \\
\text { organization }\end{array}$ & None \\
\hline
\end{tabular}

39 UNPF, supra note 7. 
Esta revista forma parte del acervo de la Biblioteca Jurídica Virtual del Instituto de Investigaciones Jurídicas de la UNAM

\begin{tabular}{|l|l|l|l|l|}
\hline $\begin{array}{l}\text { Escuela de } \\
\text { parteras de } \\
\text { Tlapa de } \\
\text { Comonfort }\end{array}$ & $\begin{array}{l}\text { Tlapa de } \\
\text { Gomonfort, } \\
\text { Guerrero }\end{array}$ & 2012 & $\begin{array}{l}\text { Created by } \\
\text { the Guerrero } \\
\text { state govern- } \\
\text { ment }\end{array}$ & $\begin{array}{l}\text { Decree 1258 by } \\
\text { which the Escuela } \\
\text { de Parteras pro- } \\
\text { fesionalizadas del } \\
\text { Estado de Guer- } \\
\text { rero, is established } \\
\text { as a Public Decen- } \\
\text { tralized Body }\end{array}$ \\
\hline $\begin{array}{l}\text { Escuela de } \\
\text { la Cruz Roja } \\
\text { Bachelor's } \\
\text { Degree in } \\
\text { professional } \\
\text { midwifery } \\
\text { and repro- } \\
\text { ductive } \\
\text { health }\end{array}$ & \begin{tabular}{l} 
Morelos \\
\hline
\end{tabular} & 2015 & $\begin{array}{l}\text { No informa- } \\
\text { tion available }\end{array}$ & No \\
\hline & & & \\
\hline
\end{tabular}

1 https://asociacionmexicanadeparteria.org/educacion/.

2 http://casa.org.mx/escuela-parteras/.

3 https://www.facebook.com/Centro-de-Iniciaci\%C3\%B3n-a-la-Parter\%C3\%ADa-en-laTradici\%C3\%B3n-de-Nueve-Lunas-Oaxaca-1582405792020383/.

4 http://wwre.mujeresaliadas.mx/pr_educativo.html.

5 http://guerrero.gob.mx/articulos/marco-juridico-de-la-escuela-de-parteras-profesionales-del-estadode-guerrero-opd/.

6 http://wrwes.ssm.gob.mx/portal/page/seic/archivos/Parteria.pdf.

The schools in Oaxaca and Michoacán are civil associations that do not give official professional certification.

In the case of the undergraduate degree offered in Morelos, we have not been able to obtain information so as to determine whether the first generation with graduate with professional certification.

These schools (officially recognized or not) were founded mostly during the last decade in an effort to create more training centers as part of Mexico's response to international guidelines, such as UNFPA, WHO and ICM proposals. These schools also give more options to women who want other forms of childbirth care, distancing themselves from the hospital model where the possibility of receiving bad treatment during childbirth or of having a Csection without medical justification is higher, as documented by authors like Ana Prado ${ }^{40}$ or Georgina Sánchez. ${ }^{41}$

40 Ana Prado, Mujer y Salud. Miradas en Torno al Nacimiento, III (6) CLIVAjes. REVISTA DE CIENCIAS SOCIALES 79-91 (2016).

41 Georgina Sánchez, Espacios para Parir diferente, un aCErcamiento a CaSas de parto en México (El Colegio de la Frontera Sur) (2016). 
It is also interesting to note that midwives can work in three different environments: birth centers, home visits ${ }^{42}$ or in a hospital.

A birth center $(\mathrm{BC})$ is a place that attends low risk births. Various approaches are available, such as providing women information about pregnancy, childbirth and postpartum; promoting vertical births and other free positions to give birth; limiting episiotomies; promoting immediate breastfeeding; and late tying of the umbilical cord, all of which are provided for in NOM007. Birth centers also make it possible for the father or other family members to be present at the childbirth. They are a private non-hospital service located in urban areas, whose facilities often look like a house. In case of emergencies, an action plan is established with the pregnant woman so she can have access to a medical facility as quickly as possible. ${ }^{43}$

It is important to mention that although midwives are best known for birth care, their work is not limited to that. There is documented evidence of their caring for a wide range of ailments such as the threat of miscarriage, vaginal infections, women's normal physiological functions (such as postpartum, breastfeeding and menopause), contraception and pap smears. ${ }^{44}$ Hence, they are health professionals that focus on sexual, reproductive and post-reproductive health throughout women's lives.

We will proceed to analyze the principle problems that professional midwives face in their work.

\section{Main Difficulties in Practicing Midwifery in Mexico}

To show the main problems in midwifery work, we will discuss the difficulties midwives face in Mexico, which are: a) the lack of recognition of midwifery as a profession, $b$ ) the difficulty of finding work in a government health facility, c) the near impossibility of practicing at a birth center, $d$ ) limits on giving out and signing birth certificates, and e) conflicts when contacting medical or hospital services to handle emergency situations.

In regard to midwifery being recognized as a profession, Marisol Escudero explains that each state sends out its list of professions. As a result, some states recognize midwives, accept midwife training and issue professional certification, but others do not. ${ }^{45}$ This means that Mexico does not have uniform na-

42 Hanna Laako, Mujeres situadas. Las parteras autónomas en méxico (EL Colegio DE LA Frontera Sur) (2017).

43 Cristina Alonso, Alison Banet, Janell Tryon, Luna Maya, Una casa de partos femifocal, in Imagen instantánea de la PARTERía 265-294 (Georgina Sánchez ed., El Colegio de la Frontera Sur, Asociación Mexicana de Partería, 2015).

44 Georgina Sánchez et al., Las condiciones de las parteras tradicionales en Chiapas, in IMAGEN instantánea de la Partería 133-150 (Georgina Sánchez ed., El Colegio de la Frontera Sur, Asociación Mexicana de Partería, 2015).

45 Marisol Escudero, Speech at Centro de Estudios Superiores de México y Cen- 
tional criteria. For example, states that do not include midwifery on their list of professions are: Aguascalientes, Baja California Norte, Campeche, Coahuila, Colima, Nuevo León, Oaxaca, Tamaulipas and Guanajuato. ${ }^{46}$

The question that arises here is why is it so difficult to validate professional midwives and open new midwifery training schools in a country like Mexico where 3,530,000 births are reported every year ${ }^{47}$ and where quality of birth care is seriously questioned as seen in an increased number of unnecessary $\mathrm{C}$-sections and obstetric violence?

One school calls attention to the problem and suggests a solution. In the state of Guanajuato where midwifery is not included on its list of professions, the Centro para los Adolescentes de San Miguel de Allende Asociación Civil A.C (CASA) signed an agreement with the state Department of Education, (Agreement 76-97 July 4, 1997. C.C.T. 11PETO143N), which authorizes the school to issue professional certification for midwife technicians. This could be an option for several institutions where the absence of professional certification is used as an excuse to block new programs from being opened.

Additionally, Escudero mentions the Health Secretary of Mexico (SSA) has only specified 43 positions for professional midwives, demonstrating that the possibility of working in a government health facility is limited due to the lack of positions, though it is no impossible. ${ }^{\mathbf{4 6}}$

Georgina Sanchez's work documents the difficulties midwives face, specifically in terms of the legislative framework that would cover birth centers. Currently, birth centers do not have the legal status to care for healthy women with low-risk births at their facilities because Mexican regulations state that birth care only refers to hospital care. This means that the concept of a birth center does not exist per se in legislation.

Because of this, some midwives with professional certification have opened birth centers only to discover that their birth care facility does not officially exist. Therefore, they get work permits to operate as private clinics or hospitals even though they are not the appropriate professionals to work there. In this way, care in birth centers remains on the fringes of the law without a legal framework to regulate such places. In contrast, the concept of birth centers exists in other countries without any major difficulties or differentiation from hospital childbirth care because they work together with the hospital system to ensure the welfare of maternal and newborn health. ${ }^{48}$

troamérica, Midwifery and Human Rights Symposium, Mexico Legal Framework (october 22 2015)

46 Georgina Sánchez, Espacios para parir diferente, un acercamiento a casas de parto en MéXico 209-223 (El Colegio de la Frontera Sur 2016).

47 UNPF, WHO, IMC. El estado de las parteras en el mundo, 134. HACIA EL ACCESO UNIVERSAL a la salud, un derecho de la mujer. Fondo de Población de las Naciones Unidas (2014).

48 Denis Walsh, Improving Maternity Services: Small is Beautiful: Lesson from a Birth Centre (2006). 
Another obstacle reported in the last two annual conferences of the Mexican Midwives' Association A.C (November 2016 and 2017) and in the Senate midwifery forum (March 2017) is related to issuing and signing birth registrations, which are needed to get the newborn's birth certificate. Authorities require that the registrations be signed and stamped by a health institution that can issue said registrations to midwives at its discretion depending on the region and its personal relationship with the midwives. This greatly hampers their performance and autonomy in childbirth care and becomes a way of controlling midwives because they are subject to the whims of the civil servants who issue said documents.

Furthermore, according to the 2013 MacArthur Foundation report, professional midwives encounter difficulties in establishing contact with medical and hospital services for emergency care. When there is an obstetric emergency and a woman is referred to a health institution, especially a government one, midwives report that they are often badly treated. This includes being accused of malpractice or of being the ones who caused the problem. ${ }^{49}$ What Escudero calls disconnected services and the necessity to establish good relationships between health institutions and professional midwives all the time, particularly in emergency situations, is clearly observed. ${ }^{50}$

Based on the problems stated, we can affirm that a regulatory framework is needed. This has led some groups of professional midwives to discuss this lack of legislation and their proposals include requests for official certification of their profession.

A group of AMP midwives has focused their efforts on certification - meaning a process to evaluate their abilities in childbirth care based on the competencies proposed by the International Midwives Confederation. They have also considered ISO certification, ${ }^{51}$ which would help guarantee midwives' services. In this way, the user would interpret the certification as a validation for safe, quality services not only for the mother, but also for the newborn. (Field Notes October, November and December 2017).

While ISO is an organization that certifies quality processes and is often used in industry, it does not certify people or professions. Therefore, it would not be the proper way to certify midwifery as it does not guarantee official

Also see E Groh, Birth center Midwifery Down Under in birth Centers: a social Model from maternity Care. Books for Midwives (Mavis Kirkham ed., 2003).

49 Macarthur Foundation, Diagnóstico situacional de la partería profesional y l a ENFERMERÍA OBSTÉTRICA EN MÉXICO: INFORMe FINAL (2013)

50 See Irazu Gomez, Echar valor. Parteras tradicionales en el contexto biomédico DEL SECTOR SALUD. Master's degree Thesis in Anthropology. UNAM-CIMSUR. San Cristóbal de las Casas, Chiapas, Mexico (2017).

51 ISO is a non-governmental organization established in 1947. Its mission is to promote the development of standards and their related activities in order to facilitate the exchange of goods and services, and to promote cooperation at intellectual, scientific, technological and economical levels. (Consulted at https://wrere.gestiopolis.com/que-es-iso/april 17, 2018) 
recognition by the State or the Ministry of Health. Even so, the Mexican Midwives' Association is already using this certification as a work standard and promoting it on its website. ${ }^{52}$

This situation reveals the problems that professional midwives face, not only in terms of their training, but also in the practice of their profession.

\section{Discussion: Criticism and Proposals for National Legal Regulation}

In this article we have established that Mexican laws and regulations provide a certain degree of support for professional midwives' training and work. However, we also find several limitations, as seen in the previous section. Some such obstacles stem from omissions in the regulatory framework because it does not explicitly recognize midwifery as a profession, nor does it specify the roles of professional midwives. In addition, there is no mention of possible places to give birth other than in a hospital setting.

The lack of consistent recognition of midwifery as a profession affects midwives in their daily work. In order to promote midwifery as a viable training option, a curriculum that establishes the appropriate knowledge and abilities is required. Professional certification is also necessary, as well as officially recognized and regulated work spaces. This requires approval at both state and federal levels, with validation from their respective institutions - including the Ministries of Education and of Health. Without these requisite elements, inconsistencies will persist among the legal framework, regulations, state guidelines and federal legislation. This directly affects the options that Mexican women of reproductive age have to choose the place and type of care they wish for giving birth, as well as other reproductive health services. More importantly, these shortcomings act against their human rights, mainly those related to sexual and reproductive health.

With respect to birth centers, it will be necessary to revise or broaden the scope of the regulatory framework that restricts low-risk birth care in places other than a hospital environment, emulating other countries where birth centers legally exist. These birth centers give maternal care in coordination with hospitals, with midwives and doctors working together based on the principle that each has a specific job and that such alliances enhance the care women receive. In Mexico, this could and should be done.

At the national level, the General Agreement for Inter-institutional Collaboration in the case of Obstetric Emergencies was passed to benefit pregnant women's health through a ruling that gives them access to medical services regardless of their insurance type and protects the midwives who bring them. ${ }^{33}$

\footnotetext{
52 Asociación Mexicana de Partería A.C. certificación (mar 16, 2018 2:15PM) https://
} asociacionmexicanadeparteria.org/certificacion/. 
This agreement was created to protect the health of women and children as well as the rights of professional midwives. This means that legally midwives should not face resistance in accessing hospital services for their patients in case of an emergency. Unfortunately, in reality midwives find it very difficult to arrange medical services with hospitals as previously discussed.

Another important issue in need of attention at the legislative level is the unpublished guideline establishing birth care work standards for midwives The Technical Regulation of the Competencies Required for the Holistic Care of Women and Babies Before, During and After the Birth, of 2007. This regulation was written to establish criteria for the evaluation and certification of the work of both technical and traditional midwives; however the project was never published in the Official Federal Record (DOF in Spanish).

With respect to the Mexican Midwives' Associations proposal asking for a process that evaluates their childbirth care abilities based on work competencies recommended by the International Midwives Confederation and possible certification through ISO, there are certain limits. ISO would not be the most appropriate route for certification because it accredits quality processes and not people or professions. While good for quality in industry, it would not guarantee official recognition by the State or the Ministry of Health. It could, however, be used to justify the existence of birth centers. Here we see the importance of a nationwide certification of work competencies for the holistic care of women and children before, during and after the childbirth. With that, the Mexican State, or SSA, can guarantee midwifery services that have been certified as safe for mothers as well as newborns.

With the actions mentioned, the regulation of places for professional midwife training and birth care provided by professional midwives is possible. What is needed is to create processes that will regulate, organize, standardize and legalize what midwives do to thus guarantee their rights. To take it one step further, the State can even establish directories listing midwifery services throughout the country. As mentioned, this is contained in the proposals by international organizations like the UNFPA, WHO and ICM. Moreover, these issues pertain to human rights, especially sexual and reproductive rights, to be enjoyed in the broadest possible interpretation of right to health, therefore honoring Alma Ata's proposal.

\section{Conclusions}

At an international level, the UNFPA, WHO, and the ICM have stressed the importance of professional midwifery as a first option for low-risk childbirth care, as stated in the midwifery proposal for 2030. These organizations urge member countries (Mexico, among them) to improve the training and education as well as workplaces of midwives to increase and improve professional midwifery. This is widely supported by contemporary scientific research in various countries. 
Currently, there are international documents (conventions, conferences and international recommendations) that serve as a reference point for rewriting of regulations, rules, and public policy on properly regulated birth care by professional midwives in Mexico. As a result, mothers who use midwifery services would be ensured that the midwives who offer these services have adequate professional training to confront the challenges of women's health in Mexico, practicing their occupation without the risk of having it happen in a legal vacuum.

We need to consider the fact that in Mexico, $70 \%$ of the states already recognize midwives as professionals. In the state of Guanajuato, where midwifery is not recognized as a profession, an agreement was reached in 1997 to create the first school of professional midwifery in Mexico, which provides technical training. Subsequently, in Tlapa de Comonfort, where midwifery is registered as a profession, a specific judicial framework was created and used to establish a second school in 2012. Following the established models in Guanajuato and Tlapa de Comonfort, a curriculum for technical midwives and a degree in professional midwifery could be standardized in each Mexican state. This could be stipulated at the federal level so that regulation would cease to be a problem and more midwifery schools could be opened at both technical and professional levels. For example, in Morelos, a state where the midwifery profession is registered, there are schools which are teaching a similar curriculum, yet neither the professional nor technical degree exists. If more states were able to offer an official degree, the number of professional midwives across the country would increase, giving women of reproductive age in Mexico more options to exercise their human right to care during their pregnancies, childbirth and postpartum.

It has been shown that there are regulations that govern technical midwifery, but it is still necessary to regulate facilities that are not part of a hospital, such as birth centers, at both rural and urban level, (but not under the model of Casas Maternas). ${ }^{53}$ This would open care options for pregnant women and in turn uphold that which is stipulated in Articles 1, 4 and 5, as previously mentioned, of the Mexican constitution.

Likewise, the development and publication of work competency standards on birth care provided by midwives is a yet unresolved legislative matter. Such standards would provide Mexican women with another option that guarantees respect for their sexual and reproductive rights.

We have stressed the importance of the judicial framework that already exists and urge that these regulations and standards be implemented in daily life to benefit pregnant women, newborns and professional midwives to allow human rights, in their broadest sense, to be respected since these are rights that everyone in Mexico should enjoy.

53 Rogelia Cruz, et al., La casa materna de comitán, chiapas: los antecedentes y aportes en la atención del embarazo y riesgo obstétrico, in: IMAGEN InSTANTÁNEA DE LA PARTERÍA 239-255 (Georgina Sánchez, El Colegio de la Frontera Sur, Asociación Mexicana de Partería, 2015). 